\title{
R Plasmids from Yersinia
}

\author{
By S. KIMURA, T. IKEDA, T. EDA, YOHKO MITSUI \\ AND KAZUE NAKATA \\ Department of Bacteriology, Teikyo University School of Medicine, 2-I I-I, \\ Itabashiku, Tokyo I73, Japan
}

(Received 25 April 1976; revised 24 June 1976)

\section{INTRODUCTION}

The recipient ability of Yersinia pestis and Yersinia pseudotuberculosis for $\mathbf{R}$ plasmids was demonstrated in the primary period of $R$ plasmid research (Ginoza \& Matney, 1963). Afterwards, transfer of $\mathrm{R}$ plasmids to $Y$. enterocolitica was confirmed by several workers (Knapp \& Lebek, 1967; Rusu, Baron \& Lazaroae, 1970 ; Kimura et al., I975a) and transfer to $Y$. pseudotuberculosis was shown by Zaremba (1972). However, there are few reports of detection of $\mathrm{R}$ plasmids in naturally occurring $Y$. enterocolitica and $Y$. pseudotuberculosis (Cornelis, Wauters \& Bruynoghe, 1973; Kimura et al., 1975b; Ikeda, Eda \& Kimura, 1975).

Classification of $\mathrm{R}$ plasmids by incompatibility was initiated by several workers (Watanabe et al., I964; Meynell, Meynell \& Datta, 1968; Chabbert et al., 1972). The distribution of incompatibility groups was examined, not only in wild-type strains of Shigella, Escherichia and Salmonella, but also in Proteus rettgeri (Coetzee, Datta \& Hedges, 1972), Proteus morganii (Hedges et al., 1973), Pseudomonas aeruginosa (Datta et al., I97I ; Datta \& Hedges, 1972), Aeromonas liquefaciens (Aoki et al., 1971), Providence (Hedges, 1974) and Serratia marcescens (Hedges, Rodriguez-Lemoine \& Datta, I975). The epidemiology and classification of these plasmids were summarized by Datta $(1975 a, b)$.

In this paper, we describe patterns of drug resistance, $f i$ types and incompatibility grouping of plasmids from six strains of $Y$. enterocolitica and $Y$. pseudotuberculosis obtained in Japan.

\section{METHODS}

Yersinia strains. All 42 strains examined were isolated from the intestinal contents of swine, except one $Y$. pseudotuberculosis strain that came from a human patient with gastroenteritis. Of the 37 strains of $Y$. enterocolitica, of three different serotypes $(\mathrm{O}-3, \mathrm{O}-5$ and O-9), 29 were drug-sensitive, four were resistant to streptomycin alone, three to streptomycin and tetracycline, and one to ampicillin, streptomycin and tetracycline. All five $Y$. pseudotuberculosis strains were resistant to streptomycin alone.

Escherichia coli $\mathrm{KI} 2$ strains. These were: $\mathrm{J}_{53}, \mathrm{~F}^{-}$lac ${ }^{+}$met pro; $\mathrm{J} 53 \mathrm{nal}$, a nalidixic-acidresistant mutant of $\mathrm{J}_{53}$; w3104, $\mathrm{F}^{-}$gal $\lambda^{--}$; w3IO4 rif, a rifampicin-resistant mutant of w3I04; wi 895, Hfr met.

Plasmids. Standard plasmids, one of each of I6 incompatibility groups (Hedges, 1974), were kindly supplied by Drs Yoshikawa and Arai (who had received them from Dr N. Datta). The standard N group plasmid, N3 (Datta \& Hedges, 197I), determined resistance to streptomycin $(\mathrm{Sm})$, tetracycline $(\mathrm{Tc})$ and sulphonamides $(\mathrm{Su})$. R plasmids from Yersinia strains are shown in Table $\mathrm{I}$. 
Table I. Nature of $R$ plasmids from Yersinia strains

\begin{tabular}{|c|c|c|c|c|c|c|}
\hline $\begin{array}{c}\text { Plasmid } \\
\text { designation }\end{array}$ & Strain of origin & $\begin{array}{l}\text { Resistance } \\
\text { markers* }\end{array}$ & $f i$ type & $\begin{array}{c}\text { Exclusion } \\
\text { of } \mathrm{N}_{3}\end{array}$ & $h s p I I$ & $\begin{array}{c}\text { Incompatibility } \\
\text { group }\end{array}$ \\
\hline pTEIOI & Y. pseudotuberculosis тateishi & $\mathrm{Sm}$ & - & - & - & $\mathbf{N}$ \\
\hline pTEIO2 & Y. pseudotuberculosis TPI004 & $\mathrm{Sm}$ & - & + & + & $\mathbf{N}$ \\
\hline pTE2OI & Y. enterocolitica $\mathrm{Y}-42$ & $\mathrm{Sm}$ & - & + & + & $\mathbf{N}$ \\
\hline pTE2I I & Y. enterocolitica $\mathrm{TP} 83$ & $\mathrm{Sm}, \mathrm{Tc}$ & - & NT & + & Undesignated \\
\hline pTE2II-I $\dagger$ & Y. enterocolitica $\mathrm{TP} 83$ & $\mathrm{Sm}$ & - & + & + & $\mathrm{N}$ \\
\hline pTE2I2 & Y. enterocolitica $\mathrm{TP} 83$ & Tc & - & - & - & Undesignated \\
\hline pTE213 & Y. enterocolitica ТР 247 & $\mathrm{Sm}, \mathrm{Tc}$ & - & + & + & $\mathbf{N}$ \\
\hline pTE2I4 & Y. enterocolitica ${ }^{\top} \mathrm{P} 248$ & $\mathrm{Sm}, \mathrm{Tc}$ & - & + & + & $\mathrm{N}$ \\
\hline
\end{tabular}

Phages. PIkc and $\lambda$ were used for the $h s p I I$ restriction test and $f_{2}$ for the $f i$ determination test.

Media. Liquid medium was Bacto-Penassay broth (Difco). Plating medium was Heart Infusion nutrient agar (Eiken).

Transfer experiments. Donor culture $(0 . \mathrm{I} \mathrm{ml})$ and recipient culture $(0.9 \mathrm{ml})$ were added to $4.0 \mathrm{ml}$ Penassay broth. After 3 or $24 \mathrm{~h}$ incubation at $37^{\circ} \mathrm{C}, 0 . \mathrm{I} \mathrm{ml}$ portions of the mixture were inoculated on agar plates containing streptomycin $\left(25 \mu \mathrm{g} \mathrm{ml}^{-1}\right)$ or tetracycline (I 2.5 $\mu \mathrm{g} \mathrm{ml}^{-1}$ ) and nalidixic acid $\left(25 \mu \mathrm{g} \mathrm{ml}^{-1}\right)$.

Plasmid incompatibility and entry exclusion. Methods were as described by Coetzee et al. (1972).

$f i$ determination. The method of Watanabe, Fukasawa \& Takano (1962) was used. Hfr strains of $E$. coli KI2 WI895 (NR84) and WI895 (NR45) were used as $f^{+}$and $f^{-}$controls respectively.

Restriction and modification of phages. The hspII restriction by $\mathrm{R}$ plasmids was determined as described by Bannister \& Glover (I968). Phages PI kc and $\lambda$ were each propagated on $\mathrm{w}_{3} \mathrm{IO}_{4} \mathrm{R}^{-}$and on $\mathrm{w}_{3} \mathrm{IO}_{4}\left(\mathrm{~N}_{3}\right)$. R plasmid N3 determines $h s p I I$ restriction and modification specificity (Hedges, 1972). Each phage preparation was titrated on w3 IO4 $\mathrm{R}^{--}$and on the same strain carrying $\mathrm{N}_{3}$ and each of the Yersinia $R$ plasmids; efficiencies of plating (e.o.p.) were compared.

\section{RESULTS AND DISCUSSION}

Transfer of drug resistance to Escherichia coli $\mathrm{KI} 2$. The $\mathrm{I} 3$ resistant strains were examined for transfer of R plasmids to $E$. coli $\mathrm{KI} 2$. Such plasmids were detected in six strains (Table 1). These R plasmids could also re-transfer to E. coli $\mathrm{KI}_{2} \mathrm{~W}_{3} \mathrm{IO} 4$ rif. One strain (TP83) of $Y$. enterocolitica transferred $\mathrm{Tc}$ resistance and $\mathrm{Sm}, \mathrm{Tc}$ resistance separately to the recipients (Table I).

$f$ character of Yersinia plasmids. All R plasmids derived from Yersinia were found to be $f^{-}$.

Compatibility of $R$ plasmids from Yersinia among the standard plasmids. Because the Yersinia plasmids were all $f^{-}$they were not tested for compatibility with F-like plasmids. In the first tests, Yersinia strains were used as donors, the recipients being $E$. coli $\mathrm{K}$ I 2 strains carrying standard plasmids of known compatibility groups with distinguishable resistance markers. By this means it was shown that the Yersinia $\mathrm{R}$ plasmids all co-existed stably with plasmids of groups $\mathrm{I} \alpha, \mathrm{I} \gamma, \mathrm{P}, \mathrm{A}, \mathrm{C}, \mathrm{J}, \mathrm{H}, \mathrm{L}$ and $\mathrm{S}$, i.e. they belonged to none of these groups. However, the compatibility of the Yersinia plasmids with plasmids of groups $\mathrm{N}, \mathrm{W}$ and $\mathbf{M}$ 
could not be tested in this way, since we had no standard plasmids of those groups that lacked Sm or Tc resistance. We decided to test for phage restriction and modification $(\mathrm{r}-\mathrm{m})$ because it has been reported that all $\mathrm{R}$ plasmids with $\mathrm{r}-\mathrm{m}$ specificity $h s p I I$ fall into compatibility group $\mathrm{N}$ (Hedges, 1972) and many of the $f^{-}$plasmids previously identified in Japan belonged to group N (Datta \& Hedges, 1971).

Restriction and modification of $R$ plasmids from Yersinia. Plasmid $\mathrm{N}_{3}$ and six of the Yersinia plasmids, when present in the indicator strain w3I04, reduced the e.o.p. of PIkc or $\lambda$ at least I0o-fold. No such restriction was seen when the phage had been propagated on an $\mathrm{N}_{3}{ }^{+}$strain. No greater than threefold differences in e.o.p. were found between titrations where there was no restriction. This result indicated that these six Yersinia plasmids determined $h s p I I$ (Table I) and suggested that they belonged to incompatibility group $\mathrm{N}$.

Compatibility of $R$ plasmids from Yersinia with $N_{3}(S u, S m, T c)$. The frequency of transfer of $\mathrm{N}_{3}$ (per donor bacterium in $24 \mathrm{~h}$ mating) was measured using, as recipients, w3 IO4 rif $\mathrm{R}^{-}$and w3 104 rif carrying each of the Yersinia plasmids. With five of the plasmids so tested, the frequency of transfer was reduced by at least 200 -fold compared with that of the $\mathrm{R}^{-}$ control, i.e. entry exclusion of $\mathrm{N}_{3}$ was demonstrated (Table $\mathrm{r}$ ).

The $\mathrm{w}_{3} \mathrm{ro}_{4}$ rif $\mathrm{R}^{+}$transconjugants from the above experiments were then used as donors, the recipient being $\mathrm{J} 53 \mathrm{nal}$ and selection being for Sm and Tc resistance separately. Only the whole $\mathrm{N}_{3}$ resistance pattern was observed to be transferred, never the resistance pattern of the Yersinia plasmid without $\mathrm{N}_{3}$. This was taken as evidence that the Yersinia plasmids had been eliminated from the $\mathrm{w}_{3} \mathrm{IO}_{4}$ rif strains on the introduction of $\mathrm{N}_{3}$, i.e. that they were incompatible with $\mathrm{N}_{3}$.

The nature of the $\mathbf{R}$ plasmids derived from Yersinia is summarized in Table $\mathbf{I}$.

Strains of Escherichia (Otaya et al., 1975) and Shigella (Tanaka, Tsunoda \& Mitsuhashi, I975) isolated in Japan during the past 4 to 7 years have most frequently been resistant to four drugs (streptomycin, tetracycline, chloramphenicol and sulphonamide) and most plasmids from those strains belonged to incompatibility group FII (Datta, I975b). However, drugresistance patterns of strains from Salmonella were mostly $\mathrm{Sm}, \mathrm{Tc}$ and plasmids from them were mostly $f^{-}$(Nakaya, Yoshida \& Terawaki, 1975) and belonged to incompatibility group N (Datta, I975a). It seems that plasmids from Yersinia isolated in Japan resemble those from Salmonella.

We thank Dr Kanazawa, Niigata Railway Hospital, Drs Zen-Yoji and Maruyama, Tokyo Metropolitan Research Laboratory of Public Health, and Drs Sasagawa and Ikemura, Niigata Prefectural Institute of Health, for providing several strains which were used in this investigation.

\section{REFERENCES}

Aoki, T., Egusa, S., Ogata, Y. \& Watanabe, T. (197I). Detection of resistance factors in fish pathogen Aeromonas liquefaciens. Journal of General Microbiology 65, 343-349.

Bannister, D. \& Glover, S. W. (I968). Restriction and modification of bacteriophages by $\mathrm{R}^{+}$strains of Escherichia coli KI2. Biochemical and Biophysical Research Communications 30, 735-739.

Chabbert, Y. A., Scavizzi, M. R., Witchitz, J. L., Gerbaud, G. R. \& Bouanchaud, D. H. (I972). Incompatibility groups and the classification of $f^{-}$resistance factors. Journal of Bacteriology 112, 666-675.

Coetzee, J. N., Datta, N. \& Hedges, R. W. (1972). R factors from Proteus rettgeri. Journal of General Microbiology 72, 543-552.

Cornelis, G., WaUters, G. \& Bruynoghe, G. (1973). Resistances transferables chez des suches sauvages de Yersinia enterocolitica. Annales de Microbiologie (Institut Pasteur) 124A, 299-309.

DatTA, N. (1975a). Classification of plasmids into compatibility groups: Distribution of genes among the groups. Microbial Drug Resistance, pp. 83-91. Edited by S. Mitsuhashi and H. Hashimoto. Tokyo, Japan: University of Tokyo Press. 
Datta, N. (19756). Epidemiology and classification of plasmids. Microbiology-1974, pp. 9-15. Edited by D. Schlessinger. Washington, D.C. : American Society for Microbiology.

Datta, N. \& Hedges, R. W. (I97I). Compatibility groups among $f^{-}$R factors. Nature, London 234, 222223.

Datta, N. \& Hedges, R. W. (1972). R factors identified in Paris, some conferring gentamycin resistance, constitute a new compatibility group. Annales de l'Institut Pasteur 123, 779-883.

Datta, N., Hedges, R. W., Shaw, E., Sykes, R. B. \& Richmond, M. H. (197I). Properties of an R factor from Pseudomonas aeruginosa. Journal of Bacteriology 108, I 244-I 249.

Ginoza, H. S. \& Matney, T. S. (I963). Transmission of a resistance transfer factor from Escherichia coli to two species of Pasteurella. Journal of Bacteriology 85, 1 177-1 178 .

Hedges, R. W. (1972). Phenotypic characterization of $f^{-} \mathbf{R}$ factors determining the restriction and modification hspII specificity. Molecular and General Genetics II5, 225-233.

HedGes, R. W. (1974). R factors from Providence. Journal of General Microbiology 81, 17I-18I.

Hedges, R. W., Datta, N., Coetzee, J. N. \& Dennison, S. (I973). R factors from Proteus morganii. Journal of General Microbiology 77, 249-259.

Hedges, R. W., Rodriguez-Lemoine, V. \& Datta, N. (1975). R factors from Serratia marcescens. Journal of General Microbiology 86, 88-92.

IKedA, T., EdA, T. \& KImURA, S. (I975). Detection of R plasmids from Sm,Tc resistant strains of Yersinia enterocolitica. Medicine and Biology 91, 365-369.

Kimura, S., Eda, T., Ikeda, T. \& Mizuno, T. (1975a). Transfer of R plasmids to Yersinia enterocolitica. Medicine and Biology 9r, 35-40.

Kimura, S., Eda, T., Ikeda, T. \& Suzuki, M. (1975b). Detection of conjugative R plasmids in genus Yersinia. Japanese Journal of Microbiology 19, 449-45I.

Knapp, W. \& LebeK, G. (1967). Übertragung der infektiösen Resistenz auf Pasteurellen. Pathologie und microbiologie 30, $103-12 \mathrm{I}$.

Meynell, E., Meynell, G. G. \& Datta, N. (i 968). Phylogenic relationships of drug-resistance factors and other transmissible bacterial plasmids. Bacteriological Reviews 32, 55-83.

Nakaya, R., Yoshida, Y. \& Terawaki, Y. (I975). Antibiotic resistance and R plasmids in Salmonella isolated from humans in Japan (1966-1972). Microbial Drug Resistance, pp. 237-252. Edited by S. Mitsuhashi and H. Hashimoto. Tokyo, Japan : University of Tokyo Press.

Otaya, H., Machihara, S., Yoshimura, M. \& Yamamoto, M. (i975). Multiply drug-resistant Escherichia coli isolated from clinical specimens. Microbial Drug Resistance, pp. 201-208. Edited by S. Mitsuhashi and H. Hashimoto. Tokyo, Japan: University of Tokyo Press.

Rusu, V., BARON, O. \& LAZAROAE, D. (I 970). Transfert du facteur de resistance (R) des Enterobacteriaceae à Yersinia enterocolitica. Archives roumaines de pathologie expérimentale et de microbiologie $29,57 \mathrm{I}-58 \mathrm{I}$.

Tanaka, T., Tsunoda, M. \& Mitsuhashi, S. (1975). Drug resistance in Shigella strains isolated in Japan from 1965 to 1973. Microbial Drug Resistance, pp. 187-199. Edited by S. Mitsuhashi and H. Hashimoto. Tokyo, Japan: University of Tokyo Press.

Watanabe, T., Fukasawa, T. \& TAKano, T. (I962). Conversion of male bacteria of Escherichia coli KI 2 to resistance to $f$ phages by infection with the episome 'resistance transfer factor'. Virology 17, 218-219.

Watanabe, T., Nishida, H., Ogata, C., Arai, T. \& Sato, S. (I964). Episome-mediated transfer of drug resistance in Enterobacteriaceae. VII. Two types of naturally occurring R factors. Journal of Bacteriology 88, 7 I $6-726$.

ZaremBa, M. (1972). In vitro and in vivo transfer of the $\mathrm{R}$ factor to Yersinia pseudotuberculosis cells. Bacterial Plasmids and Antibiotic Resistance, pp. 37-42. Edited by T. Watanabe. Prague: Avicenum Czechoslovak Medical Press, Prague. Berlin, Heidelberg and New York: (Springer Verlag). 